\title{
Double Jeopardy: The Fate of Intermarriage and Justice in the Films Redemption Road and Max and Hélène
}

\author{
Phyllis Lassner
}

check for

updates

Citation: Lassner, Phyllis. 2021. Double Jeopardy: The Fate of Intermarriage and Justice in the Films Redemption Road and Max and Hélène. Humanities 10: 6. https://doi.org/ 10.3390/h10010006

Received: 10 November 2020 Accepted: 24 December 2020 Published: 29 December 2020

Publisher's Note: MDPI stays neutral with regard to jurisdictional claims in published maps and institutional affiliations.

Copyright: () 2020 by the author. Licensee MDPI, Basel, Switzerland. This article is an open access article distributed under the terms and conditions of the Creative Commons Attribution (CC BY) license (https: / / creativecommons.org / licenses/by/4.0/).
Weinberg College of Arts and Sciences, Northwestern University, Evanston, IL 60208, USA; phyllisl@northwestern.edu

\begin{abstract}
Intermarriage between Jews and non-Jews during the Third Reich occupied a dangerously ambiguous position. Although the 1935 Nuremberg Laws declared intermarriage illegal, the Jewish wife or husband was at first exempted from anti-Semitic persecution. After Kristallnacht on 9 November 1938, their situation deteriorated dramatically. However, Nazi family law was applied inconsistently, leaving both spouses in states of uncertainty with regard to their marriages and children. This essay examines the representation of intermarriage in two films: the 2015 Italian film Max and Helene, and Redemption Road, a 2016 two-part German miniseries. With hybrid cinematic styles, narrative trajectories, and characterizations, these films dramatize the traumatic consequences of Nazi racial ideology and practices for two intermarried couples and their children. Spanning the years 1938 through the late 1940s, intermarriage in these films raises challenging questions about survival, reconciliation, and loss and the definition and achievement of legal, ethical, and emotional justice in the aftermath.
\end{abstract}

Keywords: Holocaust film; intermarriage and Nazism; anti-Semitism; post-Holocaust reconciliation; Mischlinge; Nuremberg laws; Holocaust sexual violence

\section{Introduction}

Studies of intermarriages spanning many countries over the late nineteenth and throughout the twentieth century reveal that

In effect, every marriage is mixed: whether by gender, age, kinship, religion, nationality, or citizenship (or a combination of those and other characteristics). In practice, however, the state and civil actors in our studies have understood "intermarriage" and "mixed marriage" to mean a union between a man and a woman across recognized religious, national, or racial lines. (Edgar and Frommer 2020, p. 6)

Diverging from this universal template with a racialist state agenda, marriages between Jews and Christians in Nazi Germany occupied an ambiguous position, vacillating between tolerance and punishment. Before the Nazi era, the status of approximately 35,000 couples living in mixed marriages in Germany was relatively neutral (Buettner 1989 , p. 271; Meyer 2000, p. 55). One reason was that most Jews married to non-Jewish partners were already assimilated and some baptized their children (Strnad 2015, p. 174). Although these mixed marriages were classified as privileged, racial status was also based on gender: it was the non-Jewish husband who endowed the family with privilege (Raggam-Blesch 2019, p. 385). Dangers surfaced immediately after 1933 when the Nazi regime placed "tremendous social pressure" on intermarried couples by bribing and threatening "'Aryans' to divorce their Jewish spouses" (Fachinger 2004, p. 163). Those who complied left their Jewish partners in a state of "ostracism and impoverishment", losing 
their work and threatened with imprisonment and murder as time went on (Fachinger 2004, p. 163). ${ }^{1}$

Once the 1935 Nuremberg Laws were passed, intermarriage became illegal and subject to punishment. Until 1938, however, intermarried families were protected from deportation. The reason for this leniency was to avoid arousing suspicion or protest from non-Jewish family members and to encourage Mischlinge (mixed children) to integrate into Aryan society. Integration ended completely, however, when after the siege of 9 November 1938, anti-Jewish legislation removed the exceptional status of "privileged mixed marriages'" (Buettner 1989, pp. 273, 266). ${ }^{2}$ The status of intermarried couples then plummeted. Spouses who affiliated with Jewish communities were extremely vulnerable, as were "their children, grandchildren and any other offspring" (Buettner 1989, p. 266). ${ }^{3}$ Intermarried Jews and their children were threatened with deportation and death because they represented a blight on so-called Aryan purity. Nonetheless, until early 1945, privileged Jews were exempt from the deportations that began in October 1941 unless "either divorce or the death of the "Aryan" partner ended the marriage" (Meyer 2000, p. 62). Since Nazi family law was applied inconsistently and local perpetrators threatened them, both spouses suffered acute anxiety about their individual fates and those of their marriages and children. Mischlinge could pass as German for a while, but in accordance with antisemitic ideology, they would ultimately reveal his or her Semitic markings and be punished for them.

This essay examines the representation of intermarriage in the 2015 Italian television film Max and Hélène (Giacomo 2015) and the two-part 2016 German television miniseries Redemption Road (Glasner 2016). With hybrid cinematic styles, narrative trajectories, and characterizations, these films dramatize the traumatic consequences of Nazi racial ideology and practices for two intermarried couples and their children. ${ }^{4}$ Spanning the years 1938 through the late 1940s, these films depict intermarriage as occupying a dangerously ambiguous position and raising challenging questions about the nature of legal, ethical, and emotional justice in the aftermath. Following Kobrynskyy and Bayer's approach to recent Holocaust films, my close readings of the "temporal duality" of Max and Hélène and Redemption Road, dramatizing both the historical moment of their narratives and its aftereffects, reveals a "self-reflexivity" [that] is notably allied with cinema's ambition to contribute to righting the wrongs of the past" (Kobrynskyy and Bayer 2015, pp. 3, 5). Self-reflexivity is apparent in such techniques as counterpointing realist cinematic styles with gothic and surrealistic palettes to dramatize critical relationships between historical and subjective experiences and past and present, and the intergenerational relationship between intermarried couples and their children. The focus on intermarriage also begs the question of its place in Holocaust history and cultural studies. Although both films depict the violence of Nazi domination, the aftermath, represented as internalized torture, is the locus of meaning of survival. Tatjana Lichtenstein asserts the importance of intermarriage as a multifaceted perspective on Nazi racial culture:

If the subject of intermarriage in Nazi Germany seems tangential to the tragedy of destroying entire communities, it reveals the innumerable intertwined strands of racial, social, and other persecutory categories that left no one safe. Intermarried families and intimate relationships between Jews and non-Jews are particularly rich sources because they deal with an intersection of otherwise segregated worlds. As a result, mixed couples have served as favored themes for screenwriters and producers in many countries since the end of the war. (Lichtenstein 2016, p. 122)

1 By 1939 about 330,000 Jews lived in Germany, among them 20,000 who were intermarried (Strnad 2015, p. 173). The numbers dropped to about 16,000 in 1942 and about 12,000 at the end of 1944, shortly before the last deportations (Sapir 2017, np).

2 Nazi officials increased "pressure on mixed marriages from 1943 onward, thus massively threatening their existence" (Strnad 2015, p. 175).

3 Categories designating those who were worthy or unworthy blended gender into race and religion "to differentiate Jewish Germans from Protestant and Catholic Germans" (McKinley 2020, p. 36).

4 Liebman asserts the importance of grounding "claims about traumatic representation" in historical research (Liebman 2010, p. 212). 
Among the cinematic forms that engage the subject of intermarriage in Max and Hélène and Redemption Road are flashbacks, visual metaphors, and literary references. The techniques of both films respond to what David Patterson has argued are the philosophical and ethical foundations of translating Holocaust experience into artistic forms:

Any attempt to address the problem of Holocaust representation [ . . ] ] is itself a representation of the Holocaust and therefore problematic. [ ... ] it singles me out, from beyond the ontological realm of speculation, to summon me to an absolute ethical responsibility, and not to an empathetic cry of pain. [ ... ] Far more difficult than the representation of the unimaginable is the representation of everything imaginable..$^{5}$ (Patterson 2018, pp. 3, 7)

Pertinent to this essay is the representation of stories that purport to be based on documentary and oral testimony but are fictionalized with hybrid narrative aesthetics. In combination, these elements form a kaleidoscope of narrative perspectives that reflects critically on the films' thematic questions of loss and justice.

The cinematic styles and iconographies of Redemption Road and Max and Hélène illuminate how the ambiguities of Nazi family policies created circumstances that entrapped mixed families in psychological, cultural, and ethical binds. Redemption Road is adapted from Ursula Krechel's (2012) novel Landgericht (District Court), which is based on her research into files disclosing the life of Richard Kornitzer, a German Jewish judge, during the Third Reich and its aftermath. The film covers a ten-year period from December 1938 when Kornitzer, his non-Jewish wife Claire, a commercial film producer, and their children are separated, followed by their postwar attempts at reconciliation. In its hybrid iteration, the film employs Expressionist design and references to Hansel and Gretel. Max and Hélène, based on Simon Wiesenthal's 1982 testimonial novel Max and Helen, recounts the story of forbidden love between a non-Jewish woman and her Jewish husband. ${ }^{6}$ Both films question the viability of post-Holocaust reconciliation and justice for victims and survivors. In contrast, the 2003 German film (von Trotta 2003) Rosenstrasse asserted a successful resistance of non-Jewish wives to the arrest of their Jewish husbands with an uplifting resolution. ${ }^{7}$ Earlier films, such as the East German Marriage in the Shadows (Maetzig 1947) and the Czech feature Distant Journey (Radok 1948), portray intermarriage as fraught with persistent threats and agonizing decisions that lead to the compromised and tragic fates that befell most victims. ${ }^{8}$

Both Redemption Road and Max and Hélène feature non-Jewish women protagonists who as Aryans residing in Nazi Germany and Nazi occupied Italy might very well have been ignored had they not formed intimate relationships with Jewish men. Since Jewish blood was considered poisonous, non-Jewish partners were tainted and infectious. To counteract this plague required a pseudo-forensic vigilance that became increasingly punitive over time. Yet despite these exacting discriminations, intermarried families occupied disjunctive positions in Nazi policies. As Bukey posits, "the idea of being part-Jewish and part-German made little sense in a society based on notions of discrete races" (Bukey 2010, p. 80). If poisonous Jewish blood was to be drained from the Reich, what about the Aryan blood that flowed through the veins of half-Jewish half-German offspring? According to Nazi racial ideology, Mischlinge lacked "a stable identity" because "the Jew can 'pass' as a German for a while, but s/he will ultimately reveal his/her Semitic markings" (Fachinger 2004, p. 155).

These ideological vicissitudes left intermarried families in a state of unrelieved tension that is represented in Max and Hélène and Redemption Road by merging and altering the

5 That over forty books about the challenges of Holocaust representation were published over the past 25 years demonstrates the concern (Patterson 2018, p. 1).

6 Baron's chapter "Condemned Couples" analyzes the responses of Jewish-non-Jewish lovers to "peer pressure and state law" (Baron 2005, p. 103).

7 Kapczynski observes that "the trope of 'Jewish-gentile' romance has emerged as a key theme in German historical cinema since unification ... " (Kapczynski 2015, p. 118).

8 Golan notes that no films depict Jewish women who were protected by their non-Jewish German husbands. Instead, literature describes "women abandoned by their husbands and left to go defenseless to their deaths" (Golan 2011a). 
conventional plotting of tragic romance, family melodrama, and political thriller. Both films also reject the uplifting message of survival as a triumph. ${ }^{9}$ Instead, these films show that regardless of physical survival, choices informed by psychological, legal, and ethical pressures lead to failed or tenuous resolutions involving family reconciliations and social reintegration. In both films the women protagonists survive but are doubly punished, with irreparable physical violence and emotional loss. Neither woman finds solace or justice with the defeat of the Third Reich. The Jewish male protagonists survive only to find themselves estranged from their wives and children and from possibilities to reconstitute justice from the ashes of Nazism.

\section{Redemption Road}

Redemption Road begins when the stability and prosperity of the intermarried Kornitzers and their children are being ambushed as the 1935 Nuremberg Laws explode into the 1938 siege on Jews and their property ${ }^{10}$ Richard and Claire Kornitzer are preparing their young children, Georg and Selma, to leave on the Kindertransport. Their collective anxiety, expressed through dim lighting, gray coloration, and the camera's staccato-like panning among the characters, is captioned by Richard's statement, "They only allow Jewish children to go to England, not adults". As the camera pans to Selma's forgotten doll and tracks the family's walk to the train through a dark tunnel, there are no reassurances on offer. Being told "you can finally go to school again" will not mitigate the children's impending loss of family, home, and security. Even if they all survive, the possibility of reunification is put in doubt when the camera points to a Jewish shop window smeared with a Jewish star and "Jude". The scene immediately following, in which Richard and Claire lie in bed holding each other, ironically portends the Nazi threat to their marriage as well.

In this moment of December 1938, the film establishes a cultural context for the Kornitzers' previously stable life by juxtaposing the lethal designs of Nazi racialized modernity with the design of the family's home. The apartment's unembellished and aesthetically integrated modernist décor provides a visual analogue to the progressive modernity represented by the Kornitzers' assimilated lives, distinctive careers, and mutual love and respect. That this liberal idyll is about to end is forecast with a flashback to 1933, in which a wide angle shot focuses on a Nazi banner overtaking a Berlin building. With narrative economy, the film conveys its "historical consciousness" by visualizing Nazism's iconic symbol as the flashpoint for the Kornitzers' story (Hirsch 2004, p. 89). A quick succession of scenes traces the erasure of German Jews from the Nazi system of justice. Arriving in court, Richard is rebuffed with the pronouncement that "Non-Aryan civil servants must stay at home until the new law takes effect". In tandem with his dismissal, despite her non-Jewish German identity, but because she is married to a Jew, Claire loses her business to the Reich's Aryanization process. The Kornitzers' debasement is encapsulated in a scene where bargain hunters traipse through their apartment, sneering at the modernist artifacts. That Claire's ostracism is now final is evinced at the scene's end that shows her moving tiny pieces of furniture in an otherwise empty dollhouse. The only home now available to her lies in despairing nostalgia.

Dramatizing how intermarried couples were stigmatized, Claire's suffering parallels Richard's rejection by a colleague: "Should I not grab the opportunity? Out of solidarity with you?". With no reference or depiction of community affiliation or support, the film highlights the Kornitzers' isolation as punishment for their marriage. Historically, however much Jewish families suffered along with their communities, mixed families dealt with "discrimination and persecution alone" (Tent 2003, pp. 15-16). Redemption Road tracks the myriad forms of Nazi persecution that enforce the estrangement of the Kornitzers from each other, their children, and from any community. In turn, their displacement reflects the effects of various imbalances in Germany's treatment of intermarried couples

9 Among the latter are autobiographical films (Agniezska and Telmar Film International 1991) Europa Europa and Run Boy Run (Danquart 2013).

10 Krechel spent 10 years researching the book that earned her the German Book Prize (See Otte 2012). 
and their fate elsewhere. That other nations complied with Nazi emigration restrictions is dramatized in a succession of brief scenes in which the Kornitzers fail to find a safe haven. Richard's attempts to obtain transit and entry visas for himself and Claire are foiled by every consulate to which he applies until bribery gains him entry to Cuba, but alone. His ten-year exile in Cuba, inserted into the Berlin narrative, and filmed with ironic import in surreal color, is a bittersweet interlude. Although Cuba saves Richard's life, Claire never arrives, but he finds a new love and fathers a child. Ultimately, however, as though Nazi racism remains a haunting presence, the replication of mixed racial coupling leads once again to abandonment and loss.

When the narrative returns to Claire, she has been abandoned to the will of the Reich. Her futile attempt to barter a diamond bracelet for a transit visa underscores the loss of her value as an Aryan woman married to a Jew. Demonstrating the double bind in which she is placed, she is also told that as a non-Jewish German she must remain in the country, a fate that subjects her to robbery and rape by the Gestapo. That Richard had the bracelet refashioned from his mother's tiara is a bitter reminder of the prosperity and stability once enjoyed by his assimilated Jewish family. Although neither Richard nor Claire are imprisoned or murdered, the couple is punished by an irrevocable state sanctioned crime: dispossession, which becomes their social and political location, their homeless address. Since the reach of Nazi persecution prevents the Kornitzers from finding or communicating with each other during their separation, the roads they travel are not on the way to any meaning of reunion or redemption.

As the narrative of rupture and dislocation continues into the postwar, it disallows Claire and Richard the regeneration of their self-determination, their mutual love, and a just legal system. The film recounts Germany's failure to enact denazification when Claire applies for compensation at the end of the war and is informed that as an Aryan German, she could not have suffered National Socialist persecution and that her fears could have been allayed by separating from her Jewish husband. Since she exercised her free will, she bears responsibility for her fate. When Richard returns to Germany and regains his judgeship, but loses his case on behalf of Jewish restitution, the film implies that both he and Claire are victims of the state's failure to reform. ${ }^{11}$ As Tony Judt reports, "throughout the years 1945-1949 a consistent majority of Germans believed that 'Nazism was a good idea, badly applied'" (Judt 2005, p. 58). Like a repetition compulsion, the new Germany remains shackled to the old. Nowhere is this conflation of past and present more apparent than in the film's postwar urban scenes that resemble the rubble films of the late 1940s. According to Robert Shandley, these "are films that take the mise en scène of destroyed Germany as a background and metaphor of the destruction of German's own sense of themselves" (Shandley 2001, p. 2). In the postwar time frame, Germany has not yet earned redemption and has none to offer its surviving Jewish citizens or those Germans who chose Jews to love and marry. When Krechel's novel won the German Prize, she said that it "was also a personal method of atonement for the victims of National Socialism. [ ... ] Many victims are still waiting for at least legal recognition of their suffering, not to mention material compensation" (Otte 2012).

\section{The Children's Story}

The suffering of the Kornitzer children is dramatized as integral to their character development, the psychological impact of the alienation produced by Nazi policies towards intermarried families. Although they escape the draconian fate Nazi Germany would have assigned them and ultimately find a nurturing home in England, their odyssey is replete

11 The Allies' denazification programs confronted such problems as the Adenauer administration's refusal to accept, "beyond reparations to Israel, any real responsibility for the crimes in question" and the "need to make Germany a central bulwark against Communism", which would be hindered by the Allies' pressure to "work through the past" (Bathrick 2007). Santner discusses Germans' inability to mourn in relation to realist film style, which promotes resolution instead of confronting the persistence of avoidance (Santner 1990). Ebbrecht-Hartmann shows that it was not until the fall of Communism in the 1990s and the 2000 International Forum on the Holocaust that "compensation and restitution" were included in German films (Ebbrecht-Hartmann 2015, p. 144). 
with deferral and desperation and with no recourse to personal, legal, or material compensation. The effects of their precarious status as Mischlinge reflect the ambivalences they suffer in both Germany and Britain. Although the Kindertransport saved approximately 10,000 Jewish children, its placement process responded to the immediate crisis and did not prepare or account for the trauma of the children's separation from their parents. Placement was geared to finding people who would foster the child refugees, regardless of the hosts' ability to understand the children's anxious responses and their Jewish identities and differences. Despite the significant impact of the Kindertransport on the children and on British culture, because the children were never on the run, hidden, or incarcerated, as they grew to adulthood, they were not encouraged to feel that they were part of Holocaust history. ${ }^{12}$ It was not until 1989, at the first Kindertransport reunion, that the rescue became part of "collective public awareness" (Benz et al. 2004).

Although the film is historically contextualized, the children's narrative is presented in a non-realist cinematic idiom that resembles both the plotting of fairy tales, particularly Hansel and Gretel, and the suffering of Dickens' child characters. The fairy tale iconography encapsulates the vicissitudes of the Kornitzer children's experiences in England, including their trauma inducing encounters, wandering, and "involving the eternal processes of growing up, acquiring knowledge, and claiming a place in the world" (Smith 2013, np). In Remembrance Road, however, the knowledge the children acquire and the place to which they lay claim demands a disjunctive resolution. ${ }^{13}$

The first chapter in the Kornitzer children's English saga is filmed in dark shades of gray, registering their loss of home and family in the foreboding setting in Northern England: a dark neo-Gothic house surrounded by a bare, colorless landscape, devoid of life. The welcoming kindliness of their foster host is shattered instantly by his wife Mary whose cruelty belies the iconic maternalism her name invokes, and instead rivals that of the wicked stepmother or witch. At dinner she tells Georg and Selma that because she saved them and is now their mother, she expects them "to obey her. [ . . . ] Your mother is dead. I'm your mother now". It therefore comes as no surprise when Selma asks Georg, "Is she a witch?". Despite Georg's plea to stay with his sister, Mary isolates them in rooms designed to incite nightmares. Alone in her dark, cavernous, but claustrophobic bedroom, Selma's fears are expressed in the flickering light of an oil lamp, as though it sympathizes with her trembling. The only comfort afforded the children is virtual, a letter from Claire, read as her voiceover. That family love and protection exist only in memory and imagination is evident when Georg reenacts his mother's soothing presence and reads to Selma. When Richard briefly visits the children on his way to Cuba, both foster parents look on incredulously, as though family love, an incarnation of repellent otherness, has invaded their forbidding story. What constitutes the realism of this segment of the film are the irreparable cultural and familial ruptures inherent in the children's rescue. After a series of Mary's censures and punishments, the children run away, an escape from psychological terror but not its lasting effects.

Kindertransport memoirs reveal that the fostering experience was filled with cultural and psychological complications and that not all foster parents considered expressions of nurture and compassion to be their responsibility. Moreover, regardless of language, religious, and other cultural differences, the children were expected to adapt. ${ }^{14}$ With no possibility of adjusting to the "witch's" lair, Georg and Selma escape, but instead of a realist narrative in which a Kindertransport agency might intervene, the film intensifies the darkness of its fairy tale template. With an unnarrated leap over three years, the children resurface in a makeshift shelter in London. Evoking another tale of imperiled children,

12 For discussion of Kindertransport literature, see my (Lassner 2008) Anglo-Jewish Women Writing the Holocaust.

13 Golan demonstrates that children in Holocaust films "serve as models through which the filmmaker shows how absurd racist Nazi thinking about Jewish children is" (Golan 2011b).

14 Kindertransport agencies and potential foster parents considered "age, social background, and character, and sex" as factors considered important to the children's integration in England (Curio 2004, p. 51). 
the dank skeletal shelter resembles Fagin's den of feral children. The set design of the building, with exposed beams and torn, dripping ceilings, also evokes the homelessness produced by German bombing, another site of physical and emotional loss and deprivation. Paula Derdiger's analysis of rubble films contextualizes this setting: "Children were a popular focus as they easily figured as unintended bearers of enormous national guilt for whom audiences were likely to feel sympathy" (Derdiger 2018). In its resemblance to Mary's home and war on the children, the desolation is overcome by Selma's development into a maternal figure, filling the shelter's emptiness with her caregiving, scavenging for food and taking care of Georg who becomes ill. That her homemaking counters Mary's emotional lacerations is shown in an image of Selma reading a children's book to another child in the shelter, just as Georg had read to her. This doubling, however, also reinforces the narrative of dispossession by reenacting what has been lost.

Although both children are ultimately embraced and thrive in the home of an empathetic English Christian farming family, unlike Hansel and Gretel, there is no path leading back to their birth parents. Instead, a postwar segment featuring Selma's return to Germany troubles the narrative of reconciliation and healing. Selma's unmitigated silence towards Claire expresses the lasting effects of their separation as a family and cultural rupture. There is no gesture or spoken language that can bridge or rectify the untraversable distance between a protected, intercultural childhood and the disorientation of escape and exile. The film establishes the import of this wound by juxtaposing a pastoral interlude and a tale of horror. A scene in a sun dappled German forest where Selma and a German boy playfully gather mushrooms suggests that she has accepted her return to Germany. However, when the setting cuts to the attic room Selma shares with her mother, the narrative confection mutates into a revenge tale in which mother and daughter become enemies. Claire's suspicion that the mushrooms Selma has cooked are toxic casts both women in the dual roles of witches and victims. Like the witch in Hansel and Gretel, Selma uses food as a weapon. Yet she is also figured as a victim, abandoned by the mother whose overwhelming power wrenches her from her beloved adoptive family and who then cages her in an alien place. In effect, both women are victims, suffering the losses perpetrated by the Third Reich as punishment for the Jewish presence in their identity and sense of belonging.

The scene's compressed expression of abandonment and loss overtakes the characters' subjectivity to personify trauma as a subject determining its own narrative. Although Selma and Georg are ultimately integrated into British life, and although Richard is reunited with his Cuban daughter, his judicial efforts to gain compensation for German Jewish survivors are rejected. Claire dies of the broken bonds of marriage and family. The film conveys no possibility of reconciliation with the past or that working through its ruptures and constructing emotional or legal justice can be achieved. The Kornitzers' Jewish connection is severed and the very idea, enactment, and even memory of an intercultural family or identity are lost. The Kornitzer story remains engraved with dislocation and dissolution.

\section{Max and Hélène}

Set in Venice, Max and Hélène begins when the romantic aura enveloping young lovers is shattered, not by internecine conflict as in Romeo and Juliet, but by the historically documented Italian Fascist laws that turned most deadly a year after the 1943 German invasion of Italy when the deportation and destruction of the nation's Jews began. ${ }^{15}$ Max Sereni, an Italian Jew, and Hélène Blondel, daughter of the French consul, are medical students whose love has already crossed cultural boundaries, as visualized in the opening scene where Max climbs gleefully over a roof to reach Hélène. A scene in the street below, however, dashes their romantic confidence. Moving between their faces, the camera both unites their perspectives and predicts their violent separation by zooming to show Fascist soldiers beating and dragging away a Jewish man.

15 Italian Jews were not deported until September 1943 when Germany invaded; out of approximately 44,500 Jews, over 7000 were killed while almost 37,000 survived (Zimmerman 2005). Space limits prevent discussing the 1990 American TV film adaption (See Saville 1990). 
Undeterred, lying contentedly in bed afterwards, the couple discusses a Renaissance painting on Hélène's bedroom wall that depicts a group of men looking away from viewers. The lovers' opposing interpretations highlight disjunctions in their identities and perspectives that they will struggle to overcome throughout the film. When Max asks Hélène what she thinks the group is looking at, she smiles and replies, "the new world", but his response undercuts her optimistic parable of self-determination: "We're looking at their backs", he tells her. If, like so much Renaissance art, the painting invites an allegorical reading of a humanist myth, for Max, it represents a dystopian present and future. He interprets the painting's symbolic representations and universal message as tethered to a far reaching but historically specific context. The picture that Max paints for Hélène's edification depicts the fate of his family who have already been murdered by the Nazis:

They are standing in a row against a brick wall: my mother, my sister, my father.

They look at me in silence. Yellow stars on their chests. Last night my mother

began to talk.

Not in a natural way. It was as though she were reading a letter.

She said, 'we are all fine here'.

The juxtaposition of a brick wall, yellow stars, and a mother's displaced voice creates a critical perspective confronting Hélène and the audience in which the dehumanized new world of the Nazis has obliterated Renaissance ideals. Max's conclusion sets the stage for the film's narrative path: "I don't see any new world".

That the Nazi vision of a new world has already entrapped the lovers is evident in the scene immediately following, in which Hélène's father confronts her with a list of Jews to be deported. Pointing to Max's name, he orders her to end the relationship, and when she protests, he exhorts, "Honor your race and our family". In his position representing Vichy France, the consul sanctions fascist racism in both domestic and political spheres, reorienting the humanist import of the Renaissance figures by turning his back on Nazism's victims. Although he never appears again, the consequences of the consul's Nazi collaboration become the film's driving force, as we see in its introduction of the Nazi Oberführer, Thomas Koeller, who instructs his timid subordinate, "You must quickly get over this feeling. It's easier just to quickly kill the mother and then throw the baby up in the air and fire, so you are not threatened by a ricochet bullet". Scenes alternating between the fates of Max and Hélène in the past and post-Holocaust present produce a skein of multiple references to Koeller's promise of Nazi terror. When Hélène joins Max in the Jewish deportation and identifies as a Jew "from this day on", her insistence that "we are the new world" exposes her optimism as an illusion generated by her previously privileged position. An "Aryan" by birth like Claire in Redemption Road, Hélène will seal her fate by marrying a Jew; she too becomes a target for Nazi sexual violence. During the transport to Poland, although a rabbi agrees to marry the lovers, and their wedding ceremony encapsulates a celebration of Jewish tradition, history intervenes. The inclusion of Hélène's face in the panoramic shot of the other targeted Jews aligns her subjectivity with theirs, portending their collective destruction.

Set against the hopelessness imprinted in close-ups of the victims' faces, the camera shifts focus to show Max as resistant, as noticing a loose floorboard that allows the couple to escape the train and even consummate their marriage. As the film's introduction indicates, however, any optimism represented by the lovers' idyll will be shattered by the omnipresence of Nazi violence, as verified in an abrupt cut into the next scene where Max and Hélène are arrested by Koeller. The Oberführer spares Hélène's life, but for the purpose of brutalizing her as his sex slave. Max endures concentration camp imprisonment and a different kind of torture in a Soviet gulag. Although we eventually learn that their terrors last until the war's end, the film represents all the years of Hélène's suffering metonymically, in one flashback. Triggered by her meeting with Simon Wiesenthal in the postwar present, her memory of Koeller is dramatized as a visual composition, a cavernous baronial schloss. In this showcase for Nazi supremacy, Koeller is both perpetrator and self-made victim, torturing himself by asking Hélène, “Why did you choose a Jew? Why 
did you want to mix?". With a gesture that expresses his contradictory passion for his "Jewish whore possession", he grabs a fistful of food and crushes it. In response, Hélène demonstrates how Nazi racialist ideology has constructed the meaning of being an Aryan woman married to a Jew. She opens her blouse to reveal Koeller's signature cigarette burns on her chest, forecasting the scars that will define her future. When the scene flashes forward to the present and then immediately back, the lack of transition positions the past within the present. Koeller may have released her, but the memory of him holding a gun to her head survives.

The scene's terse fade to fifteen years later suggests an open ending for Hélène while executing a shift in genre and conceptual orientation for the development of Max's character. Assisted by Matylda Kerr, the Polish doctor who saved his life and informs him mistakenly that Hélène is dead, Max goes undercover, penetrating a cabal of former SS officers whose motto, "No women, no Jews, Honor, Freedom, and the Fatherland", intensifies Max's desire to exact revenge on the Oberführer. To enact this plot, the film turns to narrative conventions associated with melodrama and thrillers, including disguises, perilous escapes, thwarted love, a still beautiful and stalwart heroine, and a daring but anxiety-ridden hero. If this familiar narrative template gestures towards escapist audience appeal, it also raises critical questions about any Holocaust story that interweaves terror and survival. ${ }^{16}$ For as so many memoirs and autobiographical films demonstrate, in order to construct coherent narratives, survivors' representations of extreme suffering or conditions of escape and hiding require the translation of fragmented memory images into an accessible mimetic language while representing the unimaginable. Gila S. Naveh discusses the representational and ethical difficulties involved in producing Holocaust films that encompass "an entire web of modalities and concepts such as 'victim', 'survivor', [ ... ] heroes' and 'triumph of good over evil', 'life affirming action', and other feel-good, richly signifying signs" (Naveh 2020, p. 418). Elie Wiesel ponders whether creative art and narratives can represent the "other side" of ordinary life, that of Holocaust experience, with its retreating distance of time and memory and in language and narrative forms that can only be approximate while mediated through information systems with which we are already familiar (Wiesel 1985, pp. 13-14).

The problem with familiar narrative tropes and trajectories of the thriller, including the anticipated suspense and resolution, is that their familiarity may subsume the "other side" into the comforting escapism of the unremarkable. The thrill of the chase with a satisfying defeat of the villain may overwhelm the historical actuality of inescapable and enveloping death and the exceptionality of escape and survival. For example, Max and Hélène offers a "spectacular cathartic ending" for the sadistic Oberführer that also celebrates Max's obsession (Naveh 2020, p. 418). During a celebration of his wife's birthday, Koeller and his successfully disguised postwar life are unmasked and demolished when Max exposes his villainy. As the camera enters the Koellers' dining room with Max, it pans the elegantly appointed table, creating a visual metaphor for the contented control exerted by the hosts and guests over their postwar destiny. With barely contained rage but in command, Max passes around a photograph showing the former Oberführer holding a gun against the head of a woman with a baby in her arms, documenting his earlier instructions to his subordinate and final threat to Hélène. David Bathrick argues incisively that the representation of such "incontestable evil" is not "the radicalization of some already existing ontological monstrosity", but "the emergence of something historically [... ] new" (Bathrick 2008, p. 9). Max and Hélène asks how it is possible to represent and respond justly to this historically new emanation of human evil.

Instead of representing triumph over evil, the scene is a prelude to more torment for Max. Upon learning from Wiesenthal that Hélène is still alive, he tracks her to Venice. Although her presence there memorializes their marriage, rather than restoring it, their meeting revives the hatred that did not die with Max's conquest of Koeller. As Max hides at

16 Holocaust films that challenge the possibility of escapism include Tim Blake's The Gray Zone and Laszlo Nemes's Son of Saul. 
the edge of a building facing Hélène's, he sees a young man exit her apartment and embrace her. The son that Max was denied is Koeller's, not only the result of unrelenting rape, but bearing the face of the man who cannot be eliminated, from Hélène's bodily history or Max's consciousness. Moreover, the available form of justice demands that victims relive their tortures in testifying against war criminals. Although Hélène and her son are innocent, recalling the mother and child shot by Koeller, they are enveloped by Max's anguish over the evil that will not dissipate over time, experience, or historical memory. The film ends as the boy leaves for school, Hélène notices Max, and the couple smile hesitantly at each other as a flashback takes us back to their wedding in the cattle car. Although the film's ambiguous ending leaves open the possibility of the couple's reconciliation, its hopefulness contrasts markedly with the novel where Wiesenthal's attempts to convince Max that there is a "way back to one another" fail (Wiesenthal 1982, p. 160). Like his pursuits of Nazi war criminals, Wiesenthal's efforts are as relentless as Max's, but he chooses a different form of justice. Having decided that bringing Koeller to trial would destroy Hélène and her son, Wiesenthal abandons his chase. In 1973, six years after Koeller's death in a car accident, at her son's graduation from medical school, Wiesenthal congratulates Hélène and says "write to him. Not much. Just, 'Max, I am alone now'". (Wiesenthal 1982, p. 163).

Both Max and Hélène and Redemption Road pursue a conversation about the search for justice in critical relation to grieving for the lost. The conversation is driven by Wiesenthal in his novel and film adaptation as a narrator, searcher, interlocutor, and prosecutor. Recalling his novel Sunflower, Wiesenthal's character poses questions about the post-Holocaust viability of emotional, legal, or ethical justice, as though he cross-examines his own goal to bring hidden Nazi perpetrators to trial. In Max and Hélène Wiesenthal asks if there is any kind of justice that would help Max transition from hatred to grief. Max's answer returns us to the Renaissance painting, which now hangs in Hélène's Venice apartment, a reminder of the couple's opposing interpretations with which the film began: "My wife Hélène wanted a new world. I wouldn't know what to do with your justice". The painting's repeated presence and that of Wiesenthal unify the film as critical reminders of the doubt cast by Holocaust victims and survivors on universalizing ideals of justice. Yet Wiesenthal's brief extends the connection between justice and grieving beyond the individual to that of collective memory and memorialization of the lost: "Justice, not just for only you or Hélène but for the thousands who are now silent—killed by this butcher. What debt do we owe the dead? If the innocent have to pay as well for price of bringing guilty to justice?".

Neither Max and Hélène nor Redemption Road brings the guilty to justice as assigned by law. Moreover, as Richard and Claire Kornitzer and Hélène and Max Sereni learn, there is no law that can offer compensation for the Holocaust's human losses. Instead the endings of both films offer recognition of loss and grief as described by Sigmund Freud (1929) in his letter to a friend about the loss of his daughter:

Although we know that after such a loss the acute state of mourning will subside, we also know we shall remain inconsolable and will never find a substitute. No matter what may fill the gap, even if it be filled completely, it nevertheless remains something else. And actually this is how it should be. It is the only way of perpetuating that love which we do not want to relinquish. (11 April 1929)

In their recognition of what cannot be restored to life after the Holocaust, Max and Hélène and Redemption Road memorialize the lost hopes and loves that are inseparable from survival.

Funding: This research received no external funding.

Institutional Review Board Statement: Not applicable.

Informed Consent Statement: Not applicable.

Data Availability Statement: Not applicable.

Conflicts of Interest: The author declares no conflict of interests. 


\section{References}

Agniezska, Holland, and Telmar Film International. 1991. Europa Europa. Lahn: Fachinger.

Baron, Lawrence. 2005. Projecting the Holocaust into the Present. Lanham: Rowman and Littlefield.

Bathrick, David. 2007. Holocaust Film Before the Holocaust: DEFA, Antifascism, and the Camps. Cinemas 18: 109-34. [CrossRef]

Bathrick, David. 2008. Introduction. In Visualizing the Holocaust. Edited by David Bathrick, Brad Prager and Michael D. Richardson. Rochester: Camden House, pp. 1-18.

Giacomo, Battiato. 2015. Max and Hélène. Italy: Marzo Film.

Benz, Wolfgang, Claudia Curio, and Andrea Hammell. 2004. Foreword. Shofar 23: 1. [CrossRef]

Buettner, Ursula. 1989. The Persecution of Christian-Jewish Families in the Third Reich. Leo Baeck Yearbook 34: 267-89. [CrossRef]

Bukey, Evan Burr. 2010. Jews and Intermarriage in Nazi Austria. Cambridge: Cambridge University Press.

Curio, Claudia. 2004. 'Invisible' Children: The Selection and Integration Strategies of Relief Organizations. Shofar 23: 41-56. [CrossRef]

Danquart, Pepe. 2013. Run Boy Run. Berlin: Bittersuess Pictures.

Derdiger, Paula. 2018. 'Now You're One of Us': Postwar Surveillance in Billy Wilder's a Foreign Affair. The Space Between: Literature and Culture 1914-1945. Available online: https:/ / scalar.usc.edu/works/the-space-between-literature-and-culture-1914-1945/ vol13_2017_derdiger (accessed on 28 December 2020).

Ebbrecht-Hartmann, Tobias. 2015. Locked Doors and Hidden Graves. In Holocaust Cinema in the Twenty-First Century: Images, Memory, and the Ethics of Representation. Edited by Oleksandr Kobrynskyy and Gerd Bayer. New York: Columbia University Press, pp. 141-60.

Edgar, Adrienne, and Benjamin Frommer, eds. 2020. Intermarriage from Central Europe to Central Asia Book Subtitle: Mixed Families in the Age of Extremes. Lincoln: University of Nebraska Press.

Fachinger, Petra. 2004. Hybridity, Intermarriage, and the (Negative) German-Jewish Symbiosis. Seminar: A Journal of Germanic Studies 40: 151-68. [CrossRef]

Freud, Sigmund. 1929. Letter to Ludwig Binswanger. Letters of Sigmund Freud 1873-1939. p. 386. Available online: http://www.pepweb.org/document.php?id=zbk.051.0386a (accessed on 28 December 2020).

Glasner, Matthias. 2016. Redemption Road. Germany: UFA Fiction, Mia Film, for ZDF.

Golan, Yvonne K. 2011a. Cinematic Love and the Shoah: Abnormal Love During Abnormal Times. Post Script 31. Available online: https: / /link.gale.com/apps/doc/A287867298/AONE?u=northwestern\&sid=AONE\&xid=5dfc476f (accessed on 28 December 2020).

Golan, Yvonne K. 2011b. Au Revoir, Les Enfants: The Jewish Child as a Microcosm of the Holocaust as Seen in World Cinema. Shofar 30. Available online: https://go-galecom.turing.library.northwestern.edu/ps/i.do?p=AONE\&u=northwestern\&id= GALE $\backslash$ T1 $\backslash$ textbar \{\}$A 271884933 \& v=2.1 \& i t=r$ (accessed on 28 December 2020). [CrossRef]

Hirsch, Joshua. 2004. Afterimage: Film, Trauma, and the Holocaust. Philadelphia: Temple University Press.

Judt, Tony. 2005. Postwar: A History of Europe Since 1945. New York: Penguin.

Kapczynski, Jenifer M. 2015. The Singular Jew: Representing National Socialism's Jewish Victims in Recent Historical Cinema. In Holocaust Cinema in the Twenty-First Century: Images, Memory, and the Ethics of Representation. Edited by Oleksandr Kobrynskyy and Gerd Bayer. New York: Columbia University Press, pp. 117-40.

Kobrynskyy, Oleksandr, and Gerd Bayer, eds. 2015. Holocaust Cinema in the Twenty-First Century. Images, Memory, and the Ethics of Representation. New York: Columbia University Press.

Krechel, Ursula. 2012. Landgericht. Salzburg: Jung und Jung Verlag.

Lassner, Phyllis. 2008. Anglo-Jewish Women Writing the Holocaust. Basingstoke: Palgrave.

Lichtenstein, Tatjana. 2016. 'It Is Not My Fault That You Are Jewish!': Jews, Czechs, and the Memory of the Holocaust in Film, 1949-2009. Dapim: Studies on the Holocaust 30: 117-41. [CrossRef]

Liebman, Stuart. 2010. Historiography/Holocaust Cinema: Challenges and Advances. In Cinema and the Shoah: Art Confronts the Tragedy of the Twentieth Century. Edited by Jean-Michel Frodon. Albany: SUNY Press, pp. 205-18.

Maetzig, Kurt. 1947. Marriage in the Shadows. Berlin: Deutsche Film-Aktiengesellschaft.

McKinley, Eric. 2020. Boundary Crossings and the Evolution of German Identity: Protestant-Catholic and Jewish-Non-Jewish Intermarriage 1875-1935. In Intermarriage, from Central Europe to Central Asia Book Subtitle: Mixed Families in the Age of Extremes. Edited by Adrienne Edgar and Benjamin Frommer. Lincoln: University of Nebraska Press, pp. 22-47.

Meyer, Beate. 2000. The Mixed Marriage: A Guarantee of Survival or a Reflection of German Society During the Nazi Regime. In Probing the Depths of German Antisemitism: German Society and the Persecution of the Jews 1933-1941. Edited by David Bankier. New York: Bergahn Books, pp. 54-77.

Naveh, Gila Safran. 2020. Wresting Memory as We Wrestle with Holocaust Representation: Reading Laszlo Nemes's Son of Saul. In The Palgrave Handbook of Holocaust Literature and Culture. Edited by Victoria Aarons and Phyllis Lassner. Basingstoke: Palgrave.

Otte, Ricarda. 2012. An Unflinching Look at Post-War Germany: Review of Landgericht. Available online: https://www.dw.com/en/ an-unflinching-look-at-post-war-germany / a-16294068 (accessed on 28 December 2020).

Patterson, David. 2018. The Holocaust and the NonRepresentable: Literary and Photographic Transcendence. Albany: State University of New York Press.

Radok, Alfred. 1948. Distant Journey. Czechoslovakia: Československy Státní Film.

Raggam-Blesch, Michaela. 2019. "Privileged" under Nazi-Rule: The Fate of Three Intermarried Families in Vienna. Journal of Genocide Research 21: 378-97. [CrossRef] [PubMed] 
Santner, Eric. 1990. Stranded Objects: Mourning, Memory and Film in Post-War Germany Ithaca. New York: Cornell University Press. Sapir, Yoav. 2017. Mixed Marriages in Nazi Germany. The New York Jewish Week. Available online: https:/ /blogs.timesofisrael.com/ mixed-marriages-in-nazi-germany / (accessed on 28 December 2020).

Saville, Philip. 1990. Max and Hélène. Hollywood: Turner Pictures.

Shandley, Robert R. 2001. Rubble Films. Philadelphia: Temple University Press.

Smith, Wendy. 2013. Happily Ever After: The Folk Tales Gathered by the Brothers Grimm Not Only Enchant Us; They Record the Hardships European Families Endured for Centuries. The American Scholar. 82. Available online: http://web.a.ebscohost.com. turing.library.northwestern.edu/ehost/detail/detail?vid=3\&sid=9bd619c9-ad42-4915-8927-1ad37bfab013\%40sdc-v-sessmgr0 3\&bdata=JnNpdGU9ZWhvc3QtbG12ZQ\%3d\%3d\#AN=2014384294\&db=mzh (accessed on 28 December 2020).

Strnad, Maxmillian. 2015. The Fortune of Survival: German-Jewish Intermarriage. Dapim 29: 173-96.

Tent, James F. 2003. In the Shadow of the Holocaust: Nazi Persecution of Jewish-Christian Germans. Lawrence: University of Kansas Press. von Trotta, Margarethe. 2003. Rosenstrasse. Germany: Studio Hamburg Letterbox Filmproduktion, Tele München Fernseh Produktionsgesellschaft (TMG) and Get Reel Productions (co-production).

Wiesel, Elie. 1985. Why I Write: Making No Become Yes. The New York Times Book Review, April 14, pp. 13-14.

Wiesenthal, Simon. 1982. Max and Helen. Translated by Catherine Hutter. New York: William Morrow.

Zimmerman, Joshua D., ed. 2005. The Jews of Italy under Fascist and Nazi Rule, 1922-1945. Cambridge: Cambridge University Press. 